\title{
AHMADIYAH AND THE FREEDOM OF RELIGION IN INDONESIA
}

\author{
Muhammad As'ad \\ Leiden University, The Netherlands
}

\begin{abstract}
This article analyzes the violence and Joint Ministerial Decree against Jamaah Ahmadiyah Indonesia (JAI), especially relating to freedom of religion. It argues that Indonesia has ratified the International Covenant of Civil and Political Rights (ICCPR) which guarantees the freedom of religion. In addition, Indonesia has also passed laws regarding the freedom of religion such as those in the 1945 constitution. However, these legal foundations have failed to guarantee freedom of religion in Indonesia. The violence against JAI is the proof of this Not only did the government let the incidents occur, but it also issued a Joint Ministerial Decree condemning the activities of JAI. The situation was exacerbated by the fatwa $\rightarrow$ f the Council of Indonesian 'Ulama $>$ MUI) which led to more attacks against JAI throughout the country. The article finds that the issuance of the decree was not based on need or legal basis but was an attempt to please radical groups in society.
\end{abstract}

Keywords: Ahmadiyah, freedom of religion, human rights, Indonesian Council of 'Ulama $>$ fatwa $>$

\section{Introduction}

Freedom of religion is considered a most essential right provided for every human being in the world. ${ }^{1}$ As an essential right, no one should be able to interfere with it. That is why it is common to proclaim freedom of religion before any other human right. Nor has the struggle to protect this right taken place only in this era. According

1 See Jose Casanova, "Private and Public Religion," Social Research, Vol 59, No. 1 (Spring 1992), p. 17. He mentioned that religious freedom in the sense of freedom of conscience is chronologically "the first freedom". 
to Brice Dickson, the struggle for the freedom of belief can be traced back to ancient Greece. ${ }^{2}$ For that reason, freedom of religion is regarded as an international issue and modern states tend to place it in the forefront of their constitution.

In the modern era, that is, since 1945, freedom of religion has been guaranteed by international human rights law. ${ }^{3}$ It is included in the Universal Declaration of Human Rights (UDHR) 1948. The religious rights are stated in article 18:

"Everyone has the right to freedom of thought, conscience and religion; this right includes freedom to change his religion or belief, and freedom, either alone or in community with others and in public or private, to manifest his religion or belief in teaching, practice, worship and observance". ${ }^{4}$

Furthermore, this specific article and other civil and political rights' adopted in the Universal Declaration of Human Rights were expanded and developed in 1966 into the International Covenant of Civil and Political Rights (ICCPR). The covenant includes more rules concerning the freedom of religion than UDHR such as articles on the limitation of freedom to manifest one's religion and also rules on incitement and hatred.

On 26 October 2005 the Indonesian government ratified this covenant into Law No. 12/2005 concerning ICCPR ratification. ${ }^{5}$ The explanation of Law No. 12/2005 states that Indonesia is part of an international community committed to the principles of the Universal Declaration of Human Rights. The explanation also mentions that human rights are fundamental rights inherent in human beings; for that reason, these rights must be protected, respected, maintained, and

\footnotetext{
2 Brice Dickson, "The United Nations and Freedom of Religion," International and Comparative Law Quarterly, Vol. 44, (1995), p. 330.

3 Geoff Gilbert, "Religious Minorities and Their Rights; A Problem Approach," International Journal on Minority and Groups Rights, 5 (1997), p. 97.

${ }^{4}$ http://www.un.org/en/documents/udhr/ [Accessed: 25 June 2009].

5 Based on Law no 12/2005 Indonesia has ratified on 26 October 2005, see http://www.depdagri.go.id/konten.php?nama=ProdukHukum\&op=detail_hukum\&$\mathrm{id}=166$. However according to United Nations, Indonesia ratified ICCPR on $23 \mathrm{Feb}$ 2006. Possibly Indonesia ratified it on 26 October 205, but reported to the UN on 23 Feb 2006. See http://treaties.un.org/Pages/ViewDetails.aspx?src=TREATY\&mtdsg_no $=I V-4 \&$ chapter $=4 \&$ lang $=$ en. [Accessed: 25 June 2009].
} 
should not be ignored, reduced, or seized by anyone. ${ }^{6}$ Based on this consideration, the Indonesian government decided to ratify the International Covenant of Civil and Political Rights, with the exception of article one regarding the term of self determination. ${ }^{7}$

Besides those international rules, Indonesia has also passed laws regarding freedom of religion. The 1945 constitution (UUD 1945), specifically Article 29 (part 2), states: “The state will guarantee the freedom to every resident to adhere to their respective religion and to perform their religious duties in accordance with their religion and that faith." Another regulation can be found in an amendment of the 1945 constitution, Article 28E, which states "Every person shall be free to choose and to practice the religion of his/her choice, to choose one's education, to choose one's employment, to choose one's citizenship, and to choose one's place of residence within the state territory, to leave it and then to return to it". It is also stipulated in article $28 \mathrm{E}(2)$ : "Every person shall have the right to the freedom to believe his/her faith (kepercayaan), and to express his/her views and thoughts, in accordance with his/her conscience". ${ }^{9}$ To implement this constitution, Indonesia enacted Law No. 39/1999 concerning Human Rights. It is stated, in Article 8 Law No 39/1999, that the main responsibility for

\footnotetext{
${ }^{6}$ Law No. 12/2005, accessed online at http://www.depdagri.go.id/konten.php?nama $=$ ProdukHukum\&op=detail_hukum\&id=166. [Accessed: 25 June 2009].

${ }^{7}$ It is mentioned that "With reference to Article 1 of the International Covenant on Civil and Political Rights, the Government of the Republic of Indonesia declares that, consistent with the Declaration on the Granting of Independence to Colonial Countries and Peoples, and the Declaration on Principles of International Law concerning Friendly Relations and Cooperation Among States, and the relevant paragraph of the Vienna Declaration and Program of Action of 1993, the words "the right of self-determination" appearing in this article do not apply to a section of people within a sovereign independent state and cannot be construed as authorizing or encouraging any action which would dismember or impair, totally or in part, the territorial integrity or political unity of sovereign and independent states." See http:/ / treaties.un.org/Pages/ViewDetails.aspx?src=TREATY\&mtdsg_no=IV-

4\&chapter=4\&lang=en. [Accessed: 28 June 2009].

${ }^{8}$ The translation adopted from http://dss.ucsd.edu/ mshugart/ied/pdfs/ indonesia/ indonesian_constitution_1945.doc. [Accessed: 28 June 2009].

${ }^{9}$ The translation adopted from translation made by Indonesian embassy in Canada, see www.indonesia-ottawa.org/indonesia/constitution/fourth_amendment_const.pdf.

[Accessed: 28 June 2009].
} 
protecting, promoting, upholding, and fulfilling Human Rights rests upon the government. ${ }^{10}$

From the regulations mentioned above, it can be concluded that Indonesia has made a good effort to maintain and protect religious practices for every citizen. In its constitution, enacted in 1945 by Indonesia's founding fathers, the diversity of cultures and religions in Indonesia has been fully recognized. The ratification of ICCPR and also the creation of laws concerning human rights present further proof of the serious efforts of the government in this regard. Therefore, considering these regulations, it cought to be clear that religious violence or any activity which violates the freedom of religion should not happen in this country.

Unfortunately, it is not always easy for the state to realize its will to perform well in the realm of moral and legal obligations. This reality can be seen from several incidents regarding human rights violations, especially concerning the issue of freedom of religion. These incidents started when Jamaah Abmadiyah Indonesia (JAI) held an annual meeting in Bogor, West Java. They stated that they had received the permission from the police to conduct the meeting on 15 July 2005. Nevertheless, the conference was attacked by several Islamist groups, namely Front Pembela Islam (FPI, Islamic Defenders Front) and the Lembaga Penelitian dan Pengkajian Islam (LPPI, Islamic Research and Study Institute). Coincidently, this incident ended with the announcement of the fatwa $>$ by the Council of Indonesian 'Ulama $>$ (MUI) which declared Ahmadiyah as a deviant sect and categorized as non-Islamic. ${ }^{11}$

These two occurrences led to increasing attacks on Ahmadiyah's activities and centers in some provinces. On 6 January 2006 there was

${ }^{10} \mathrm{It}$ also mentions the freedom of religion's right. It is stated in article 22 part 1 and 2; (1) Everyone has the right to freedom to choose his religion and to worship according to the teachings of his religion and beliefs, (2) The state guarantees everyone the freedom to choose and practice his religion and to worship according to his religion and beliefs. For complete text see http://hrli.alrc.net/mainfile.php/indonleg/133/. [Accessed: 28 June 2009].

${ }^{11} \mathrm{It}$ is written that Ahmadiyah doctrines is out of the path of Islam, heretical and deviating (with bold ink), and a Muslim who has joined this doctrine is an apostate. Keputusan Fatwa Majelis Ulama Indonesia No.11/Munas VII/MUI/15/2005 tentang Aliran Ahmadiyah, 29 July 2005. Article can be accessed at http://www.mui.or.id/files/11-Fat-Munas-Ahmadiyah.pdf. [Accessed: 31 October 2008]. 
an attack on an Ahmadiyah mosque in Bogor, West Java. ${ }^{12}$ It was also reported that the Ahmadiyah community in Lingsar, West Lombok was assailed by several people on 29 January 2006.13 On 17 February 2006, an Ahmadiyah center was attacked by a mob in Bulukumba, South Sulawesi. ${ }^{14}$ With these events there arose a vigorous pro-contra debate concerning the existence of Jamaah Ahmadiyah in Indonesia. This reached its peak when FPI (Islamic Defenders Front) attacked religious-tolerance activists AKKBB (Aliansi Kebangsaan untuk Kebebasan Beragama dan Berkeyakinan) on June $1^{\text {st }}$ 2008. After several more conflicts and violence occurred on 9 June 2008, the state reacted by passing a Joint Ministerial Decree "to freeze" the activities of the Ahmadiyah sect.

These occurrences led many to question whether the Indonesian government seriously promotes the freedom of religion. For this reason, this article focuses on the position of the freedom of religion in Indonesia. It particularly examines how the government interprets principles of freedom of religion, taking policies on Ahmadiyah as a case study. In the first place, the article discusses the history of Ahmadiyah in Indonesia. It then explores the position of the Council of Indonesian 'Ulama $>$ with its fatwa $>$ and its impacts regarding the violence against the Ahmadiyah.

\section{Ahmadiyah and Its Legal Position in Indonesian History}

Originally, Ahmadiyah was a religious reformist movement emerging for the first time among some Muslims of the Punjab during the last decades of the nineteenth century. According to Ahmadiyah Lahore website, it was founded around 1890.15 The founder of this movement was Mirza Ghulam Ahmad, a religious leader who declared himself a promised Messiah and Mabdi $\geqslant$ the Muslim world. ${ }^{16}$

\footnotetext{
12 “Lima Perusak Masjid Ahmadiyah Jadi Tersangka," Tempo Daily Newspaper, 9 January 2006.

13 “Terpojok di Negeri Sendiri," Tempo Daily Newspaper, 5 February 2006.

${ }^{14}$ See "Lagi Massa Serbu Markas Ahmadiyah," Indopos Daily Newspaper, 18 February 2006.

15 http:/ /ahmadiyya.org/intro/summary.pdf. [Accessed: 1 July 2009].

16 Spencer Lavan, The Ahmadiyah Movement: A History and Perspective (New Delhi: Manohar Book Service, 1974), p. 2
} 
Many Muslims, especially from mainstream Sunni>groups have rejected and condemned the group because of its teachings. Most of them consider Ahmadiyah heretics and non-Islamic. In the eyes of mainstream Sunni slam, certain Ahmadiyah ideas are seen as heretical. Among them are the claims that the founder had the ability to speak with God and regarded himself as mubdddith. Ahmadiyah also claim that Jesus didn't die on the cross, but lived and went to Kashmir and died there at the age of 120 . The most controversial idea is the claim that Allah appointed the founder of Ahmadiyah as a prophet. ${ }^{17}$ This statement emerged in 1904 when the founder stated that he indeed believed that Muhammad was the seal of the prophet, but he also believed that he himself was a prophet who had the duty to guide people before the coming of Judgment Day. ${ }^{18}$ All of these ideas are contrary to mainstream Islamic teachings, making many Muslim mainstream groups regard Ahmadiyah's teachings as heretical and people who follow them as non-Muslims.

Adherents of Ahmadiyah split into two groups after they went through a crisis of leadership, especially after the successor of Mirza Ghulam Ahmad, Nūr al-Dīn, died in 1914. ${ }^{19}$ The disagreement within Ahmadiyya created two factions, Ahmadiyah Qadiyani led by Mirza Ghulam Ahmad's son, Mahmud Ahmad, and Ahmadiyah Lahore led by Muhłmmad 'Alī and Khwāja Kamāl al-Dīn. The differences between them do not lie in terms of leadership only, but also in religious thought. Ahmadiyah Lahore is more sympathetic in approaching other Muslims; they believe that non-Ahmadis are considered Muslim. This position differs from that of the Ahmadi Qadiyani which insists that non-Ahmadis are infidels. The most important disagreement between the two groups concerns belief in the prophethood of Mirza Ghulam Ahmad. Lahore prefers to use the word mujaddid for this doctrine, not prophet. In Qadiyani belief, Ghulam Ahmad was a prophet and this religious authority is

\footnotetext{
${ }^{17}$ Encyclopedia of Islam, Accessed online at http://www.brillonline.nl/subscriber/uid $=1380 /$ entry? result_number $=1 \&$ entry=ei3_COM-0007\&search_text $=$ ahmadiyya\#hit. [Accessed: 1 July 2009].

${ }^{18}$ Francis Robinson, "Ahmad and the Ahmadiyya," History Today, 40: 6 (June, 1990), p. 43.

${ }^{19}$ Lavan, The Abmadiyah Movement, p. 106.
} 
maintained for his successor, Nūr al-Dīn, and his son Mahmud Ahmad. ${ }^{20}$

Aside from these differences, they also have common ideas, such as belief in the death of Jesus and the idea of peaceful jihat However, it is interesting to note that, even though they belong to the same root, i.e. Mirza Ghulam Ahmad's teachings, these two groups rarely cooperate with each other. Ahmadiyah Lahore deals mainly with the issue of Islamic modernism and tries to make few references which will distinguish them from mainstream Islam. The Qadiyani, on the other hand, tend to maintain the prophethood of Ghulam Ahmad and to be more sectarian than Lahore, especially in terms of missionary activity and the superiority of Islam in the Western world. ${ }^{21}$ meanwhile, both groups have expanded widely all over the world, in Europe, West Africa, and Indonesia. ${ }^{22}$

In Indonesia, Ahmadiyah appeared for the first time in $1925 .^{23} \mathrm{It}$ was first encountered when, in 1922, three Indonesian students visited India; they had heard that Islamic education in India was good and equal to the Middle East. For that reason they went there, and happened to choose Qadiyan as their place of study. These Indonesian students in Qadiyan informed their Indonesian fellows about the quality of the study and the low cost of living in Qadiyan. For poor people, it was also possible to get scholarship. Thus, they encouraged people to follow them and study at Qadiyani School. In 1924 they returned to Indonesia and asked permission to preach in Indonesia. The request was granted in 1925, whereupon Rahmat Ali, a qadiyani muballigh, went to Sumatra and undertook Ahmadi missionary activities. $^{24}$

\footnotetext{
${ }^{20}$ Encyclopedia of Islam, Accessed online at http://www.brillonline.nl/subscriber/uid=1380/entry? result _number =1\&entry=ei3_COM-0007\&search_text=ahmadiyya\#hit. [Accessed: 1 July 2009].

${ }^{21}$ Margaret Blood, "The Ahmadiyah In Indonesia: Its early History and Contribution to Islam in the Archipelago," (Unpublished Honour Sub-thesis, Department of Indonesian Languages and Literatures, The Australian National University, 1974), p. 13.

${ }^{22}$ Encyclopedia of Islam, Accessed online at http://www.brillonline.nl/subscriber/uid $=1380 /$ entry? result_number $=1 \&$ entry $=$ ei3_COM-0007\&search_text $=$ ahmadiyya\#hit. [Accessed: 1 July 2009].

${ }^{23}$ Blood, The Abmadiyah In Indonesia, p. 17.

24 Ibid., p. 19.
} 
However, according to Margaret Blood, the arrival of Ahmadiyah Qadiyani was later than Ahmadiyah Lahore. She stated that Lahore was introduced in Jogjakarta, Central Java in 1924. Unlike Qadiyani Indonesia which was derived from Indonesian students studying at Qadiyan, Ahmadiyah Lahore expanded in Indonesia through coincident activities. It was reported that the first Lahore preachers who came to Indonesia were Mirza Wali Ahmad Baig and Maulana Ahmad. Their first destination was Manila, but because they ran out of money, they were forced to stay in Indonesia. ${ }^{25}$

According to a book by Iskandar Zukarnain, in which he explains the Ahmadiyah movement in Indonesia, Ahmadiyah Qadiyani in Sumatra was rejected strongly by local ulama This refusal emerged because Qadiyani preachers, from their first arrival had begun propagating Ahmadiyya teachings to the local community. They also attacked other Muslims' beliefs, which led to their ideas being rejected by local 'ulama $\rightarrow$ t once. This behaviour was very different from that of the Lahore group, who tended to work cooperatively with other Muslims. Usually, they hid their Ahmadi identity and tried to get sympathetic responses from others. Nevertheless, after acknowledging their Ahmadi beliefs, many Muslims would immediately reject them and bar them from the Muslim community. ${ }^{26}$

In terms of formal institutions, even though Ahmadiyah Qadiyani had existed in Indonesia since 1925, the creation of its national headquarters or hoofdbestuur only occurred ten years afterwards, i.e. in 1935. Before this, they already had several provincial centres in Sumatra, Western Java and Batavia (Jakarta). The central board was established on 16 December 1935 in Jakarta. At first, this organization was called Ahmadiyah Qadiyan Department Indonesia. On December 1949, after a national conference in Jakarta, the participants agreed to change Ahmadiyah Qadiyan Department Indonesia to Jama'ah Ahmadiyah Indonesia. This organization had structural and formal relations with the Ahmadiyah Headquarters in India because its chairman (ami $\rightleftharpoons$ was responsible directly to the khalifh in Qadiyan. ${ }^{27}$

In later periods, Jamaah Ahmadiyah Indonesia (JAI) repeatedly proposed its legal existence to the Ministry of Law. After several

\footnotetext{
25 Ibid., p. 25.

${ }^{26}$ Iskandar Zulkarnain, Gerakan Abmadiyah di Indonesia (Jogjakarta: LKIS, 2005), p. 192

27 Ibid, p. 195
} 
efforts, they received ministerial decree from the Ministry of law No. JA.5/23/13 on 13 March 1953.28 By this decree, Jamaah Ahmadiyah Indonesia received acknowledgment as a legal organization by the government. Furthermore, in 2003, Jamaah Ahmadiyah Indonesia also received another legal status as a social organization from Directorate for Relations with Political Institutions of Ministry Home affairs with decision No. 75//DI/VI/2003. ${ }^{29}$ These decisions confirm the legal position of Jamaah Ahmadiyah Indonesia, since from 1953 to 2003 the government had granted them legal status. For that reason, in terms of legal existence, Jamaah Ahmadiyah Indonesia is on solid ground.

Unlike Ahmadiyah Qadiyan, Ahmadiyah Lahore in Indonesia has no structural connection with its international headquarters in Lahore. Not only does Ahmadiyah Lahore reject the idea of the prophethood of Mirza Ghulam Ahmad, it also doesn't recognize the system of khilats as performed by Ahmadiyah Qadiyani. According to Zukarnain, Ahmadiyah Lahore doesn't have an organizational structure. In most countries, Ahmadiyah Lahore consists of groups of people forming a loose association. This is the case in Indonesia, which again suggests that Ahmadiyah Lahore in this country doesn't have any structural connection with its headquarters in Lahore. Mostly, its relations are created only through letters and magazines. ${ }^{30}$

Overall, even though JAI and GAI exist in Indonesia and have several branches, in gaining followers, they can be considered to have failed. Not only have they had difficulties in gaining followers, they have also been rejected and even challenged by mainstream Islam in Indonesia especially from iulama $>$ and many Islamic organizations. Basically, they have challenged the doctrine of Ahmadiyah which proclaims that there is a prophet after Muhammad. Aside from that, many other teachings are rejected. Take for instance the acknowledgment of Mirza Ghulam Ahmad as a prophet and Imam Mahdi, his ability to speak with God, and also the claim that Jesus didn't die on the cross. These are the most controversial issues for Indonesian Islam and as any other Sunni>Muslims in the world,

\footnotetext{
28 Ibid., p. 196

${ }^{29}$ Alfitri, "Religious Liberty in Indonesia and the Rights of "Deviant" Sects," Asian Journal of Comparative Law, Volume 3, Issue 1 (2008), p. 19.
}

${ }^{30}$ Zulkarnain, Gerakan Abmadiyab di Indonesia, p. 202. 
Indonesian Muslims have reacted harshly and condemn them as nonMuslim.

\section{The Fatwa $\gg$ the Council of Indonesian `Ulama $\Varangle M U I)$ and the Attack against Ahmadiyah}

The first fatwa جegarding Ahmadiyah in Indonesia can be traced back to 1935, when Nahdlatul Ulama, nowadays known as the biggest Muslims organization in Indonesia, held a meeting to discuss Ahmadiyah. At that time they agreed to issue a fatwa rondemning Ahmadiyah as aberrant, and as infidels and apostates. ${ }^{31}$ Another fatwa $>$ was put forward five years later when an association of the 'ulama $>$ in East Sumatra issued the same fatwa which categorized Ahmadiyah as an infidel group and non-Islamic. However, though they stigmatized Ahmadiyah as a deviant sect, they had not yet reached any decision to dissolve Ahmadiyah as a religious organization. ${ }^{32}$

A fatwa om an official institution of ulama rame to the forefront much later in 1980, when the MUI issued a fatwa regarding the Ahmadiyah group. ${ }^{33}$ This fatwa was issued after the council held its second national conference on 26 May - 1 June $1980 .{ }^{34}$ At that time it was concluded that "in line with data and facts found in nine books on Ahmadiyah, the Council of Indonesian 'Ulama >issues a fatwa that the Ahmadiyah is a non-Islamic group, heretical and deviating". ${ }^{35}$ The fatwa Xas by no means the last on Ahmadiyah; it was followed by another fatwa 1984. This fatwa may be regarded as explanation of the previous one because it contains clearer views of the MUI on Ahmadiyah's doctrines. Three decisions resulted from that fatwa $>$ The

\footnotetext{
${ }^{31}$ Erni Budiwanti, Pluralism Collapses: A Study of the Jama'ah Ahmadiyah Indonesia and Its Persecution (Working Paper Series, Asia Research Institute, National University of Singapore), p. 13. Accessed from http://www.ari.nus.edu.sg/docs/wps/wps09_117.pdf. [Accessed: 1 July 2009]

32 Ibid., p. 13.

33 Official means created by the government

34 Mimbar Ulama, No. 40 (1980), p. 24. Mimbar Ulama is the official magazine of Indonesian Council of Ulama.

35 The translation of fatwa $\rightarrow$ n Ahmadiyah in 1980 adapted from Lilik Rofiqoh, "The Fatwas of the Majelis Ulama Indonesia on the Ahmadiyah doctrines, the Problem of Religious Authority and Tolerance," (Unpublished thesis, Leiden University, 2008), p. 93.
} 
decisions are (1) That the Council of Indonesian 'Ulama $>$ MUI), the provincial and districts, all ulama $>$ and preachers throughout Indonesia explain the heretical doctrines of the Ahmadiyah Qadian which are non-Islamic; (2) Those who have already joined the Jamaah Ahmadiyah Qadian should return to true Islamic doctrines; (3) Muslim communities should increase their alertness in order not to get influenced by their heretical doctrines. ${ }^{36}$

To a certain extent this fatwa as a reaction of Indonesian Muslims to the fatwa $\ngtr f$ the Muslim World League. As a member of this Muslim organization, Indonesia was supposed to acknowledge its decision. On 10 April 1974, the Muslim World League issued a fatwa $>$ which announced that Ahmadiyah was prohibited and should be considered non-Muslims. After this fatwa as enacted, several of its members, for instance Malaysia and Pakistan, decided to ban Ahmadiyah from their countries. Like them, the enactment of the fatwa $\rightarrow n$ Ahmadiyah in Indonesia can be considered an effect of the World Muslim League's fatwa $>$

However, the MUI's fatwa $\rightarrow$ ften gave a negative effect to the people, especially for those who used it as a legitimation for the violent attacks against the Ahmadiyah group. It can be said that the fatwa $>$ encouraged them to use violence, especially the violence which happened in 2005 onwards.

According to a report by The Wahid Institute, a non Governmental Organization created by former President Abdurrahman Wahid, the attack against Ahmadiyah happened when Jamaah Ahmadiyah Indonesia (JAI) held an annual meeting called Jalsah Salanah. The meeting began on 8 July 2005 in Bogor, Western Java. On the second day, 9 July, many people gathered outside the building screaming and shouting for a ban on Ahmadiyah. Many of them used sharp words, saying that Ahmadiyah was a deviant sect and should be banned from Indonesia. Their condemnation was based on the MUI's fatwasin 1980 and 1984.

The protesters even created a place in front of the conference, namely Posko Pembubaran Abmadiyab (Post for Dissolving Ahmadiyah). The crowd was led by Amin Djamaluddin, the head of Lembaga Penelitian dan Pengkajian Islam (LPPI-Islamic Research and Study

36 Mimbar Ulama, No. 323 (2005), p. 8. 
Institute). ${ }^{37}$ After several hours, the crowd started to attack the building with bottles, stones and wood. As a result of this attack, many people were injured. Furthermore, according to the investigation by the Indonesian Commission of Human rights, even though the crowd attacked the conference en masse, the participants within decided not to retaliate and remained in the building. ${ }^{38}$

The next day, 10 July 2005, a statement claiming to come from a representative of Muslims in Indonesia, demanded Bogor municipality dismiss Ahmadiyah and close their Headquarters in Bogor. This demand was followed by a threat written in block letters stating that if there was no action from the government, the crowd would react radically to dismiss and destroy Ahmadiyah headquarters. ${ }^{39}$

Because of this threat, on 14 July 2005, the leader of JAI sent a letter to the police asking for protection. The response to this letter was completely unexpected. It was answered by a letter signed by House of Representatives, district Bogor, Bogor Police department, district attorney and other municipal leaders, stating that they agreed to shut down the activities of JAI in its Headquarters in Bogor. ${ }^{40}$

On the next day 15 July 2005, as mentioned in their threatening statement, Habib Abdurrahman, a leader of Front Pembela Islam (FPI, Islamic Defenders Front) came to the Ahmadiyah Headquarters with 3000 people. He stated that if they did not eject themselves from the building, it would be burnt down and destroyed. Because of this threat, the representatives of JAI negotiated with the police and municipal staff. After these negotiations between JAI and the government, it was agreed that the participants would be evacuated by bus and truck.

During the negotiations, the crowd attacked several buildings inside the headquarters, especially in the Lajnah Imaillah site, a building which is exclusively for women's activities. The crowd burnt down several houses and other buildings, including one library. They also plundered houses where most participants stayed. Ironically, even though police officers were there, no action was taken to prevent the

\footnotetext{
37 Ahmad Suaedy (ed.), Politisasi Agama dan Konflike Komunal; Beberapa Isu Penting di Indonesian (Jakarta: The Wahid Institute, 2007), pp. 224-225.

${ }_{38}$ M.M Billah, Laporan Sementara Pemantauan Kasus Abmadiyah (Jakarta: Komnas HAM, 2006), p. 35.

${ }^{39}$ Suaedy, Politisasi Agama, p. 229.

${ }^{40}$ Ibid., p. 230.
} 
crowd from their destructive activities. Participants finally succeeded in evacuating the building while the attack and the plundering still continued. Before the crowd withdrew from Ahmadiyah headquarter, they put a banner on the building with writing "This building is sealed by Indonesian Muslims". After that incident, the municipal authority of Bogor enacted a statement letter which forbids any activities of Jamaah Ahmadiyah Indonesia in its district. This letter can be seen as confusing because JAI is the victim not the one who created the chaos, they even sent a letter to the district authority to protect their activities, but the result was shocking. The police didn't arrest any people who attack their headquarters, instead they enacted a letter which condemned and prohibited the existence of JAI headquarter in Bogor. ${ }^{41}$

After the incident, the Indonesian Council of 'Ulama $>$ MUI) held a national conference on 26-29 July 2005. According to the report published in Mimbar Ulama, the objective of MUI national conference was to give opinion regarding social issues in the society. One of the issues discussed in this meeting was regarding the Ahmadiyah case with reference to the recent incidents in order to find the appropriate reaction by the MUI on this situation. ${ }^{42}$ Based on this meeting and prior to two fatwas $>$ of the MUI resulted in 1980 and 1984, the MUI decided to create another fatwa which would ban both groups of Ahmadiyah, Ahmadiyah Qadiyan materialized in Jamaah Ahmadiyah Indonesia (JAI) and Ahmadiyah Lahore, which was never mentioned in the previous fatwa $>$ The conference itself enacted eleven fatwas $>$ regarding many issues such as, fatwa $>$ n the prohibition of pluralism, liberalism and secularism, intellectual rights and so on. ${ }^{43}$

${ }^{41}$ Ibid., p. 233.

42 Mimbar Ulama, No. 323 (2005), p. 8.

43 There are several works which discuss the role of Indonesian council of ulama, one of them is M.B Hooker in his book Indonesian Islam, Social Change Through Contemporary Fatawa, in this book he argues that the main function of the MUI especially from 1975 to 1990's is to support, and in some cases to justify government policy and programmes. See M. B. Hooker, Indonesian Islam, Social Change through Contemporary Fatawa (Hawai: University of Hawai Press). The other is Atho Mudzhar, different from Hooker who thinks that MUI's fatwa only used as legitimating the government policy, Mudzhar argues differently. He said that MUI's fatwa $>$ s not always functioned as legitimation of the government's policy, because some are against. See Atho Mudzhar, Fatwas of the Council of Indonesian Ulama: A Study of Islamic Legal Thought in Indonesia 19751988 (Jakarta: INIS, 1993). The third one is Nur Ichwan whom conclusion much the 
In the fatwa eoncerning Ahmadiyah, MUI puts an emphasis on its deviation and, once again, declares it as a non Muslim group. This fatwa $>$ also mentions two aspects which are not mentioned in the two previous fatwas? Firstly, it refers to the Muslim World League's fatwa $>$ which forbids and condemns the existence of the Ahmadiyah and secondly is the mentioning of the Ahmadiyah claim of the prophethood of Mirza Ghulam Ahmad. In short, the fatwa zomprises several decisions. First, the the fatwa $\rightarrow$ ffirms the decree of the fatwa $\gg f$ the Council of Ulama in the second conference in 1980 which decided that the Ahmadiyya's doctrines are beyond the path of Islam, heretical and deviating; and a Muslim who join this doctrine is apostate. Second, the fatwa asserts that those who joined the Ahmadiyah doctrines must return immediately to the true Islam based on the Qur'a and the tradition of the Prophet Muhłmmad. Third, the fatwa $>$ obliges the government to ban the dissemination of the Ahmadiyah doctrines throughout Indonesia and to annul the organization as well as to close down all of its offices.

The crucial point in that fatwa the third one which proposes that the government take legal measure against the Ahmadiyah group. It even states that the government must ban and close all Ahmadiyah offices in Indonesia. To support and strengthen this fatwa $>$ the MUI held several meetings in the month of August 2005, such as the meeting with other Muslims stakeholders, such as the Front Pembela Islam (FPI, Islamic Defenders Front) and the Lembaga Penelitian dan Pengkajian Islam (LPPI, Islamic Research and Study Institute) and also with the representatives of Indonesian Legislative Assembly (DPR). The result of these meetings was the decision taken by MUI to send a letter to the government declaring that Ahmadiyah had caused social

same as Hooker, he said that from its political expression, the MUI can be regarded as subjugated by the new order government. See Nur Ichwan, 'Ulama State and Politics: MUI after Suharto', Islamic Law and Society, 12, 1 (2005), pp. 45-72. However all of them agree that the notion of the MUI after reformation era (after 1998) is different from its notion before. After reformation era, the MUI has been tempted to take a side on political issues. Another postulate made by Gilispie stated that after reformation era, MUI has been influence by the hardliners within Indonesian Muslims. What happens to the fatwa against Ahmadiyah can be regarded as this influence. See Piers Gillespie, "Current Issues in Indonesian Islam: Analysing the 2005 Council of Indonesian Ulama Fatwā no. 7 Opposing Pluralism, Liberalism and Secularism", Journal of Islamic Studies, 18, 2 (2007), pp. 202-240. 
unrest and conflict within Indonesian society. Therefore MUI encouraged the government to ban Ahmadiyah doctrines and to revoke their status as an official organization. ${ }^{44}$

The controversies around MUI's fatwa and its effects on the people snowballed. Violence against Ahmadiyah increased, including the attack on an Ahmadiyah mosque in Bogor, Western Java on 6 January 2006. Also reported was an attack against an Ahmadiyah community in Lingsar, West Lombok on 29 January 2006. On 17 February 2006, another Ahmadiyah center was attacked by a mob in Bulukumba, South Sulawesi.

In time, the government, through the President, instructed the Team of the Coordinating Board for Monitoring Mystical Beliefs in Society (TIM Bakorpakem ${ }^{45}$ ) to conduct a survey on Ahmadiyah. ${ }^{46}$ The work of this team can be regarded as very long, and suppressed by demands by certain Muslim groups, as can be seen from the fact that it worked for two years from 2006 without any practical solution. In the end, they seem only to have appeased the demands of radical Muslims. On 16 April 2008 and after several mass demonstrations, the TIM Bakorpakem concluded that JAI deviated from Islam. The team also recommended that a joint ministerial decree be issued, in accordance with the 1965 law on blasphemy, warning JAI to cease its actions, and if the warning was not heeded, that JAI would be dissolved. ${ }^{47}$

Bakorpakem's conclusion provoked strong reactions, both in people who demanded the dissolution of the Ahmadiyah such as the hard-line Islamic groups, and also in Muslims who disagreed with the decision and demanded that Ahmadiyah be allowed to exist in

\footnotetext{
44 Rofiqoh, "The Fatwas of the Majelis Ulama Indonesia," p.47

45 According to International Crisis Group, Bakorpakem had been established in 1984, at the height of Soeharto-era repression, and was basically an intelligence body to monitor the innumerable sects Indonesia seems to produce, determine if they constituted a threat to the government and ban them if they did. Its legal basis was a 1965 presidential decree on blasphemy, issued by Indonesia's first president, Sukarno, just before he fell from power, and incorporated into a new security law by his successor, Soeharto, in 1969. See International Crisis Group report on Ahmadiyah, p. 3. It can be accessed at http://www.crisisgroup.org/library/documents/asia/indonesia/b78_indonesia__implications_of_the_ahmadiyah_decree.pdf. [Accessed: 1 January 2009] .

46 Budiwanti, Pluralism Collapses, p. 15

${ }^{47}$ International Crisis Group report on Ahmadiyah, p, 6.
} 
Indonesia out of respect for freedom of religion in the country. The latter even created an alliance, namely the National Alliance for Freedom of Religion and Belief (Aliansi Kebangsaan Untuk Kebebasan Beragama dan Berkeyakinan, AKKBB). Most of the members were Muslim intellectuals, journalists and other figures, including the former Indonesian President, Abdurrahman Wahid. 48 After Bakorpakem's recommendation was issued, both groups arranged repeated street demonstrations. Convinced of their own respective views, the hard-line groups demanded that the government apply the decision to dissolve Ahmadiyah as soon as possible, while the AKBB demanded the cancellation of the recommendation.

Pro and contra opinions about the existence of the Ahmadiyah group escalated until, on 1 June 2008, there was a violent clash. That day $\mathrm{AKKBB}$, including hundreds of Ahmadiyah followers, arranged a peaceful demonstration in the name of freedom of religion and religious tolerance in Indonesia. At the same time, there was another demonstration led by Hizbut Tahrir Indonesia (HTI, Indonesian Party of Liberation) and FPI to protest an increase in the oil price. Coincidently, both demonstrations were held at the same location in Jakarta and at the same time. After several hours of, the AKKBB group was attacked by the hardliners with sticks. They attacked and called for the dismissal of Ahmadiyah. This attack caused many injuries, mostly among the AKKBB demonstrators. ${ }^{49}$

Immediately the attack became a national issue. To end the controversies concerning Ahmadiyah, on 9 June 2008 the Indonesian government decided to announce a Joint Ministerial Decree banning the activities of Ahmadiyah. This decree consists of five points. First, it warns all citizens not to discuss, endorse or seek public support for an interpretation of a religion followed in Indonesia, or undertake religious activities that resemble the activities of such a religion, in a way that deviates from the central tenets of that religion. Second, it warns followers, members and/or leaders of the Indonesian Ahmadiyah Congregation (Jamaah Ahmadiyah Indonesia, JAI), as long as they claim to be Muslims, to stop dissemination of interpretations that deviate from the main teachings of Islam, that is, spreading the understanding that there was a prophet after the Prophet Mohammed.

\footnotetext{
48 Ibid., p. 6.

${ }^{49}$ Ibid., p. 7.
} 
Third, it warns that the followers, members and or leaders of JAI who do not heed these warnings and instructions mentioned above may face legal sanctions in accordance with laws and regulations. Fourth, it warns members of the public to safeguard and protect religious harmony as well as public order and not undertake actions and/or behavior that violate the law against followers, members and or leaders of JAI. Finally, it notes that members of the public who do not heed the warnings outlined in the first and fourth points above can face legal sanctions. 50

The legal basis of this decree is the law on religious deviation and offence (No. 1/PNPS/1965). Interestingly, this law was a product of the old regime under Sukarno, who created his own political concept, which he called guided democracy. Sukaron's law declares that the government or the president can ban a religious organization or sect. ${ }^{51}$

\section{Questioning the Freedom of Religion in Indonesia}

This article started with the observation that Indonesia was a signatory to the Universal Declaration of Human Rights. Not only that, Indonesia had also ratified the International Covenant of Civil and Political Rights (ICCPR), recognized as an expanded version of the UDHR. That ratification even developed into a national law (No. 12/2005). Even though Indonesian included a reservation concerning Article One, this particular article had nothing to do with freedom of religion; it dealt with the definition of the term 'self determination'. ${ }^{52}$ Considering all this, Indonesia cannot now deny the stipulations of the covenant, especially Article 18, which states that "everyone shall have the right to freedom of thought, conscience and religion. This right shall include freedom to have or to adopt a religion or belief of his choice, and freedom, either individually or in community with others

\footnotetext{
50 The English translation adapted from International Crisis Group report, International Crisis Group report on Ahmadiyah. p, 6. The full text can be downloaded from. See http://www.thepersecution.org/ world/indonesia/docs.skb.html. [Accessed: 20 July 2009]

51 Leena Avonius, "Freedom of Religion in Indonesia," ISIM Review 22 (Autumn 2008), p. 48.

52 See http://treaties.un.org/Pages/ViewDetails.aspx?src=TREATY\&mtdsg_no=IV4\&chapter=4\&lang=en. [Accessed: 25 June 2009].
} 
and in public or private, to manifest his religion or belief in worship, observance, practice and teaching". 53

Furthermore, Indonesia has plenty of rules which pertain directly or indirectly to the guarantee of the freedom of religion. The Indonesian Constitution (UUD 1945) Article 29 (part 2) clearly states this freedom. Article $28 \mathrm{E}$ also mentions that "every person shall be free to choose and to practice the religion of his/her choice". The second item of this article also mentions that people have the freedom to believe according to his or her own faith. Besides the constitution, Indonesia also lays down this freedom in Law No. 39/1999 concerning Human Rights, which stipulates that the government is responsible for protecting, promoting, upholding, and fulfilling Human Rights.

Limitations or restrictions on freedom of religion can be applied only in certain circumstances. ICCPR Article 18 (3) states that "freedom to manifest one's religion or beliefs may be subject only to such limitations as are prescribed by law and are necessary to protect public safety, order, health, or morals or the fundamental rights and freedoms of others". ${ }^{54}$ However, if we look at the Indonesian Constitution, whether the original one or amended version, there are no rules or items which contain limitations or restrictions. It mentions only freedom of religion, not its limitation. In any case, the joint ministerial decree which declared that Ahmadiyah should stop disseminating its teachings never stated that the reason for its decision was to protect public safety, order, or morality and fundamental rights of others (ICCPR' limitation). On the contrary, it was simply alleged that Ahmadiyah resembled the activities of an existing religion (Islam). Basically, if we go by Indonesian law referring to the freedom of religion, it is almost impossible to restrict a religion or believer who believes in his own religion.

However, the term 'freedom of religion' in Indonesia is different from the universal term as applied in the Western world. In UDHR or ICCPR, the term 'freedom of religion' means that people can manifest any religion, believe in it and exist alongside any other religions. In Indonesia, 'freedom of religion' means that people can embrace one of the religions recognized by the Government. In this matter, Indonesia

\footnotetext{
53 See http://www2.ochr.org/english/law/ccpr.html. [Accessed: 25 July 2009].

${ }^{54}$ Ibid.
} 
recognizes only six religions: Islam, Catholicism, Protestantism, Buddhism, Hinduism, and Confucianism. People cannot manifest a new religion or embrace a religion other those six religions, such as Judaism, Sikhism or others. If they do, they do not have the right to live and practice it in Indonesia. This arrangement is regulated by a law concerning religious deviation and offence (No. 1/PNPS/1965). The joint ministerial decree also refers to this law. In this matter, it can be concluded that religious freedom in Indonesia is not really free, because it is confined only to six religions. Therefore, even if Ahmadiyah followers declared themselves non-Muslims and decide to manifest their own religion as Ahmadiyah, as demanded by Muslim hard-liners, they would not be able to live in Indonesia.

Another question which needs to be answered is the position of the joint ministerial decree itself. In fact, such a ministerial decree should not have been issued at all. The reason is that the decree is contrary to a higher level of law, in this case, the Indonesian Constitution and also the ratification of ICCPR. The hierarchy of laws in Indonesia can be seen in the Law No. 10/2004 on regulations relating to the Constitution ${ }^{55}$. In this particular law it is stated that the highest level of law in Indonesia is Constitutional law; the second is Law or Government regulation in lieu Law; the third is Government regulation; the fourth is Presidential regulation; and the fifth is district regulation. From this we can conclude that a joint ministerial decree has no place in the hierarchy of Indonesian law, and that this decree is highly dubious and debatable, especially in terms of its position. Thus, as many humanist activists in Indonesia claimed, in light of both the Constitution and human right laws, the decree was not legally binding. They even demanded that the government annul the decree against Jamaah Ahmadiyah because in their opinion, the decree violates the Constitution and legalizes crimes against a minority Islamic group. ${ }^{56}$

This fact raises many questions, especially regarding the solution this dispute. On the one hand, Indonesia has ratified ICPPR in Law No. 12/2005, which declares the importance of freedom of religion.

\footnotetext{
${ }_{55}$ Complete draft can be accessed at http://www.depkumham.go.id/NR/rdonlyres/1727EB6A-5E5E-45B3-9414-38EC7D7F2CA7/0/UNDANGundangNo10tahun2004ttgPPP.pdf (Indonesian version). [Accessed: 1 August 2009].

56 "Ahmadiyah Decree Seen as Legalizing Violence," The Jakarta Post, 6 November 2008. Accessed online at http://www.thejakartapost.com/news/2008/06/11/ahmadiyah-decree-seen-legalizing-violence.html. [Accessed: 1 August 2009].
} 
On the other hand the joint ministerial decree condemns the existence of Ahmadiyah by forbidding their beliefs, and accuses them of deviating from Islam. Surely, these two regulations are self-contradictory and confusing, particularly for the believers of Ahmadiyah. As a consequence, many activists have requested the annulment of the joint ministerial decree, stating that in their opinion the decree does not exist in the hierarchy of Indonesian law. However, the process of annulment is not simple. One possible way to solve this problem is to review this decree in the Constitutional Court. Because ICCPR was ratified as the Law No. 12/2005, it can be said that ICCPR is domestic law, and as a result, the process of judicial review can take place through the Constitutional Court.

Nonetheless, this process too is problematic. It has been mentioned above that the joint ministerial decree does not exist in the hierarchy of Indonesian law; therefore there are doubts about the process of its judicial review. This problem is raised by Mahfud MD, chief of Indonesian Constitutional Court, who claims that the joint ministerial decree against Jamaah Ahmadiyah cannot be reviewed through Constitutional Court because the decree cannot be categorized as a law as mentioned in the Law No. 10/2004. Fortunately, Mahfud provides a solution to this matter. First, the President must annul this decree, because it was made by his ministers and the president has the right to annul it. Second, through judicial review, the law on religious deviation and offence (No. 1/PNPS/1965, not the decree itself, is revised. This law was used as the legal basis of the decree; if it is annulled, so is the decree. ${ }^{57}$

This dispute over the position of the decree results from inconsistency in the actions of the government. If the government had reacted consistently to the case of Ahmadiyah, with reference to the constitution and law, neither the decree nor the violence against Ahmadiyah would have happened. The reaction of the government to the fatwa $\rightarrow \mathrm{f}$ the MUI regarding Ahmadiyah issued in 1980's was very different from the recent reaction. In 1980's, even though the MUI condemned Ahmadiyah as a deviant sect, the government didn't react negatively but still allowed them to live and practice their rituals. However, the reaction to the fatwa $>$ in 2005 was completely different.

57 The statement can be accessed through http://www.menkokesra.go.id/content/view/8246/39/. [Accessed: 1 August 2009]. 
The government reacted negatively and abruptly issued a joint ministerial decree banning Ahmadiyah activities. According to reports by the International Crisis Group, this resulted from a consolidation of radical movements to put pressure on the government and repeated mass demonstrations demanding a ban on the Ahmadiyah group. These radical groups are based mostly in Jakarta; they are highly visible, well-organized and well-funded. To a certain extent, these radical groups have adapted well to the role of civil society in a democratic country. They are able to build networks and even create an intraparliamentary movement to press public officials to support a policy such as the joint ministerial decree. ${ }^{58}$ In other words, this decree was passed not to address the needs of society or its legal, foundations, but more as an effort to please radical groups in society.

\section{Conclusion}

It can be concluded that the freedom of religion in Indonesia is not really free. It is confined only to six religions. For that matter, living in Indonesia with a religion other than those six religions is impossible. To a certain extent, this arrangement is against the universal meaning of religious freedom as mentioned in the Universal Declaration of Human Rights (UDHR) and International Covenant on Civil and Political Rights (ICCPR)

Regarding the Ahmadiyah case, the joint ministerial decree issued by the Indonesian government violated major laws in Indonesia such as its Constitution and other higher laws, and also universal ones such as the UDHR and ICCPR. It is a fact that Indonesia has ratified both the declaration and the covenant; despite this, because of strong demands by Muslim hard-liners in Indonesia, the government went ahead and issued the decree. This decree was not really based on its benefits for society but more on certain religious and political factors. Furthermore, the decree did not take into consideration the articles of the Indonesian Constitution and, in fact, is conspicuously against the that constitution and national law. For the sake of the Indonesian Constitution and law, it is recommended by many activists that the Indonesian government annul this decree. However, with the rapid growth of the Muslims hard-liners in Indonesia, this prospect seems not very likely in the short time. What can be done is to review the

58 International Crisis Group report on Ahmadiyah, p, 6. 
decree to the Constitutional Court. This effort is not an easy task and will take much time, energy and money. But it is important to make such an effort in order to gain the supremacy of law, because if this uncertainty persists, freedom of religion in Indonesia will remain in danger, and the threat of violence will continue. []

\section{Bibliography}

\section{Books and Articles}

Alfitri. "Religious Liberty in Indonesia and the Rights of 'Deviant' Sects." Asian Journal of Comparative Law. Volume 3, Issue 1 (2008): pp. 1-27.

Blood, Margaret. "The Ahmadiyah In Indonesia: Its early History and Contribution to Islam in the Archipelago." Unpublished Honour Sub-thesis, Department of Indonesian Languages and Literatures, The Australian National University, 1974.

Budiwanti, Enni. Pluralism Collapses: A Study of the Jamaiah Ahmadiyah Indonesia and Its Persecution. Working Paper Series, Asia Research Institute, National University of Singapore, 2009.

Casanova, Jose. "Private and Public Religion." Social Research, Vol 59, No. 1 (Spring 1992): pp. 17-57.

Dickson, Brice. "The United Nations and Freedom of Religion." International and Comparative Law Quarterly, Vol. 44 (1995): p. 330

Gilbert, Geoff. "Religious Minorities and Their Rights; A Problem Approach." International Journal on Minority and Groups Rights, 5 (1997): pp. 97-134.

Gillespie, Piers. "Current Issues in Indonesian Islam: Analysing the 2005 Council of Indonesian Ulama Fatwā no. 7 Opposing Pluralism, Liberalism and Secularism." Journal of Islamic Studies, 18: 2 (2007): pp. 202-240.

Hooker, M. B. Indonesian Islam, Social Change through Contemporary Fatawa. Hawaii: University of Hawai Press, 2003.

Ichwan, Nur. "Ulama State and Politics: MUI after Suharto." Islamic Law and Society, 12.1 (2005): pp. 45-72.

Mudzhar, Atho, Fatwas of the Council of Indonesian Ulama: A Study of Islamic Legal Thought in Indonesia 1975-1988. Jakarta: INIS, 1993. 
Lavan, Spencer. The Ahmadiyah Movement: A History and Perspective. New Delhi: Manohar Book Service, 1974.

M.M Billah. Laporan Sementara Pemantauan Kasus Abmadiyah. Jakarta: Komnas HAM, 2006.

Rofiqoh, Lilik. "The Fatwas of the Majelis Ulama Indonesia on the Ahmadiyah doctrines, the Problem of Religious Authority and Tolerance.” Unpublished thesis, Leiden University, 2008.

Suaedy, Ahmad., (ed.). Politisasi Agama dan Konflik Komunal, Beberapa Isu Penting di Indonesia. Jakarta: The Wahid Institute, 2007.

Zulkarnain, Iskandar. Gerakan Abmadiyah di Indonesia. Jogjakarta: LKIS, 2005.

\section{Electronic Sources}

International Crisis Group report on Ahmadiyah, Indonesia: Implications of the Ahmadiyah Decree. http://www.crisisgroup.org/library/documents/asia/indonesia/b78 indonesia implications_of_the_ahmadiyah_decree.pdf

http://www.un.org/en/documents/udhr/

http:/ / www.depdagri.go.id/konten.php?nama $=$ ProdukHukum\&op $=\mathrm{d}$ etail_hukum\&id=166

http://treaties.un.org/Pages/ViewDetails.aspx?src=TREATY\&mtdsg _no $=$ IV-4\&chapter $=4 \&$ lang $=$ en

http://dss.ucsd.edu/ mshugart/ied/pdfs/indonesia/indonesian _constitution_1945.doc.

www.indonesia-ottawa.org/indonesia/constitution/fourth_amendment_const.pdf

http://hrli.alrc.net/mainfile.php/indonleg/133/

http://www.mui.or.id/files/11-Fat-Munas-Ahmadiyah.pdf.

http://ahmadiyya.org/intro/summary.pdf

http://www.brillonline.nl/subscriber/uid=1380/entry?result_number =1\&entry=ei3_COM-0007\&search_text=ahmadiyya\#hit

http:/ /www.depkumham.go.id/NR/rdonlyres/1727EB6A-5E5E45B3-9414-38EC7D7F2CA7/0/UNDANGundangNo10tahun2004ttgPPP.pdf 
Ahmadiyah Decree Seen as Legalizing Violence, The Jakarta Post, 6 November 2008. http://www.thejakartapost.com/news/2008/06/11/ahmadiyah-decree-seen-legalizing-violence.html

http://www.menkokesra.go.id/content/view/8246/39/

Newspapers

Mimbar Ulama, No. 40, 1980

Mimbar Ulama, No. 323, 2005

Tempo Daily Newspaper, 9 January 2006

Tempo Daily Newspaper, 5 February 2006

Indopos Daily Newspaper, 18 February 2006 